УДК [53.04+53.06] : 66.063

\title{
СТВОРЕННЯ ТА ВПРОВАДЖЕННЯ ЕФЕКТИВНИХ ТЕХНОЛОГІЙ ТА УСТАТКУВАННЯ ДЛЯ ВИРОБНИЦТВА ЛІКАРСЬКИХ ЗАСОБІВ. ЧАСТИНА 1
}

\author{
Долінський А.А., академік НАН України, Грабова Т.Л., канд. техн. наук, Степанова О.С. \\ Інститут технічної теплофізики НАН Украӥни, вул. Желябова 2а, Київ, 03680, Україна
}

В роботі розглянуто особливості отримання різних лікарських форм 3 точки зору дисперсних систем. Представлено огляд інноваційного тепломасообмінного обладнання та технологій для отримання м'яких лікарських форм, які розроблено, виготовлено та впроваджено фахівцями IТТФ НАНУ на фармацевтичних підприємствах України та за кордоном.
В работе рассмотрены особенности получения разных лекарственных форм с точки зрения дисперсных систем. Представлен обзор инновационного тепломассообменного оборудования и технологий для получения лекарственных форм, разработанных, созданных и внедренных специалистами ИТТФ НАНУ на фармацевтических предприятиях Украины и за рубежом.
The features production of different pharmaceutical forms in terms of dispersed systems is discussed in the paper. The innovative heat- mass exchange equipment and technologies for the production of pharmaceutical forms, designed, developed and implemented by the specialists of IET NASU in pharmaceutical plants in Ukraine and abroad have been reviewed.

Бібл. 13, табл. 6, рис. 6 .

Ключові слова: дисперсна система, лікарська форма, тепломасообмінні процеси, диспергування, плавлення.

ЛФ - лікарська форма;

МЛФ - м’яка лікарська форма;

Економічний стан України вимагає якісного оновлення технологій та виробництва, інтенсифікації технологічних процесів, зниження енерговитрат на одиницю продукції, заміни дорогого імпортного на вітчизняне обладнання.

Однією з галузей промисловості, яка потребує вирішення комплексу таких проблем, $є$ фармацевтична галузь. Переважно фармацевтичні препарати або лікарські форми (ЛФ) за своєю природою є різноманітними дисперсними системами. Дисперсологічна класифікація лікарських форм базується на наступних ознаках: наявність або відсутність зв'язку між частинками дисперсної системи (вільнодисперсні і зв'язано-дисперсні системи); агрегатний стан дисперсійного середовища; ступінь подрібненості дисперсної фази.

Вільнодисперсні системи поділяють на: системи без дисперсійного середовища (збори, порошки та інше); системи з рідким дисперсійним середовищем (розчини, золі, суспензії, емульсії,
ФС - фармацевтична стаття;

ГГМКК - гідрогель метилкремнієвої кислоти.

комбінації перерахованих систем); системи 3 пластично- або пружно-в'язким дисперсійним середовищем. До таких форм відносяться групи безформних систем (мазі, пасти) і формовані системи (свічки, кульки, палички); системи 3 газоподібним дисперсійним середовищем (аерозолі, аерогелі).

У зв'язано-дисперсних системах дисперсні частинки або ниткоподібні структуроутворення утворюють в дисперсійному середовищі просторові мережі та каркаси. Розрізняють системи без рідинного дисперсійного середовища: тверді пористі тіла (гранули, таблетки) i зв'язано-дисперсні системи 3 дисперсійним середовищем: концентровані суспензії, пасти, гелі.

В основі отримання ЛФ лежать технологічні процеси такі, як механічне та гідродинамічне подрібнення, перемішування, розчинення, пептизація, суспендування, емульгування, гомогенізація, екстрагування, нагрівання, 
плавлення, структурування, зневоднення, що реалізуються за рахунок комплексу тепломасообмінних та фізико-хімічних процесів. Причому, для кожної групи ЛФ комплекс і послідовність процесів, та їх теплотехнологічні параметри є індивідуальними [1,2].

Основні вимоги, які пред'являються до лікарських форм: забезпечення заданих фармакокінетичних i фармакологічних властивостей; повинні володіти певними структурно-механічними характеристиками; задана дисперсність лікарських та допоміжних речовин i рівномірний розподіл їх в основіносії; стабільність при тривалому зберіганні; відповідність заданим органолептичним показникам [3].

В ІTТФ НАН України в основі розробок тепломасообмінного устаткування та технологій одержання широкого спектру лікарських форм покладені дослідження 3 інтенсифікації процесів переносу теплоти й маси та принцип дискретно-імпульсного введення енергії (ДІВЕ) у гетерогенні середовища $[4,5]$.

На рис. 1 представлено стаціонарні установки для виробництва м'яких лікарських форм (МЛФ), до яких відноситься широкий спектр лікарських засобів на рідинній або формоутворюючій основі-носії: мазі, гелі, креми, лініменти, пасти. Установки (табл. 1) мають робочі реактори, які можуть бути об'єднані в один контур, або організувати два автономних технологічні контури. Кожна 3 установок має свої конструктивні особливості: модифікації дисково-циліндричних апаратів (ДЦА) роторнопульсаційного типу, перемішуючих пристроїв, системи нагріву, фільтри та інше. Конструктивно реактори виконані 3 можливістю термостатування (нагріву або охолодження) i перемішування субстанцій для забезпечення рівномірного температурного поля та полів густини в робочому об'ємі.

Перевага таких установок полягає в тому, що їх застосування дозволяє виконувати повний безперервний цикл технологічних операцій отримання МЛФ.

Аналіз даних (табл. 2) показує, що питомі витрати електроенергї, металоємність та вартість створеного устаткування для виробництва МЛФ у 5..10 разів менші за відповідні параметри зарубіжних аналогів.

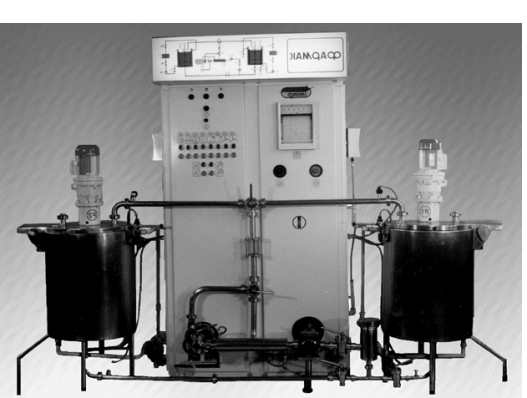

a)

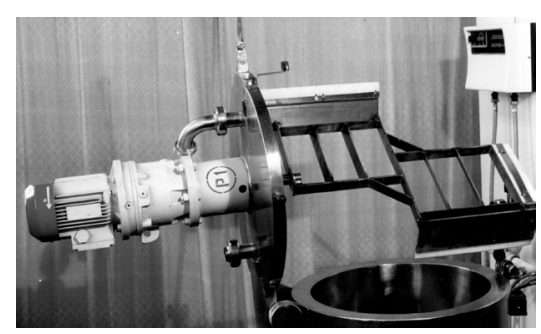

d)

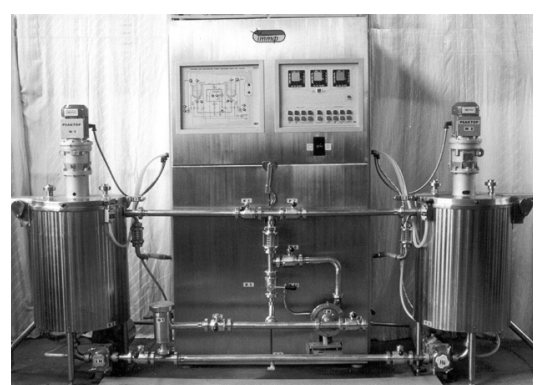

б)

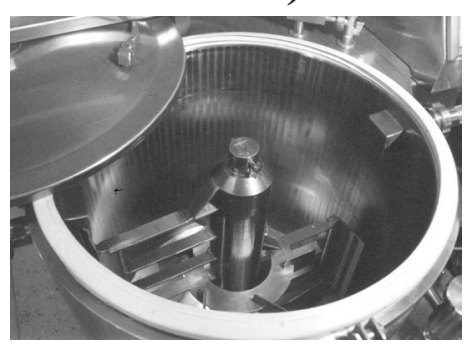

e)

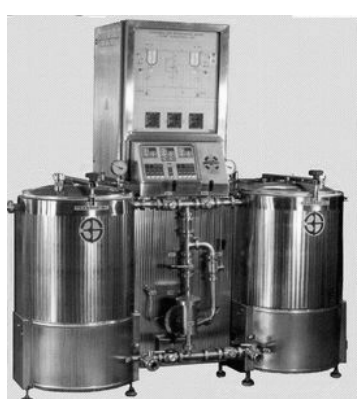

6)

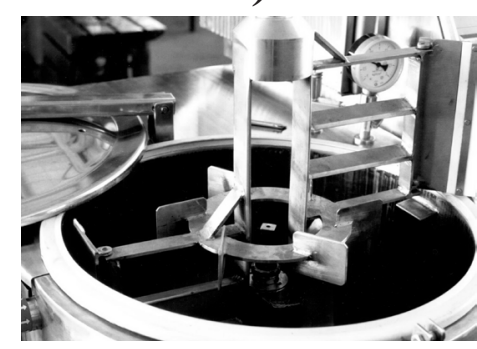

ж⿻)

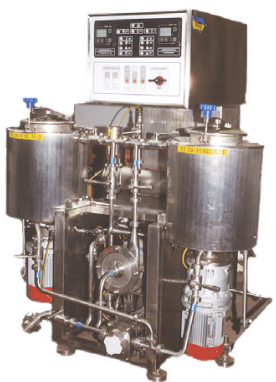

2)

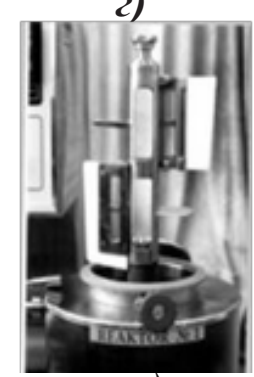

3)

Рис. 1. Модельний ряд стаціонарних установок для виробництва МЛФ(а-г) та перемішуючі пристрої до них (д-з): а,д) установка типу «Фармак»; б,д) установка типу КМ-200; в,е,жс) БФ-320; 2,3) "Мікротрон". 
Табл. 1. Основні технічні характеристики стаціонарних установок для отримання МЛФ

\begin{tabular}{|c|l|c|c|c|c|c|}
\hline $\begin{array}{c}\text { № } \\
\text { 3/п }\end{array}$ & \multicolumn{1}{|l|}{ Устаткування } & $\begin{array}{c}\text { Кількість та } \\
\text { робочий } \\
\text { об’єм ре- } \\
\text { акторів, л }\end{array}$ & $\begin{array}{c}\text { Кіл-ть } \\
\text { ДЦА, од. }\end{array}$ & $\begin{array}{c}\text { Встанов- } \\
\text { лена по- } \\
\text { тужність, } \\
\text { кВт }\end{array}$ & $\begin{array}{c}\text { Кіл-ть пе- } \\
\text { ремішую- } \\
\text { чих прис- } \\
\text { троїв, од. }\end{array}$ & $\begin{array}{c}\text { Число обертів } \\
\text { перемішуючого } \\
\text { пристрою, об./хв. } \\
\text { (розміщення при- } \\
\text { воду двигуна) }\end{array}$ \\
\hline 1. & «Фармак» (рис. 1, $a$ ) & $2 \times 100$ & 1 & 17,6 & 2 & 36 (верхнє) \\
\hline 2. & КМ-200 (рис. 1, б) & $2 \times 100$ & 1 & 25,4 & 2 & 36 (верхнє) \\
\hline 3. & БФ-320 (рис. 1, в) & $2 \times 160$ & 1 & 27,5 & 2 & $36 / 56$ (нижнє) \\
\hline 4. & «Міротрон» (рис. 1, г) & $2 \times 12$ & 2 & 9,3 & 1 & 8,3 (нижнє) \\
\hline
\end{tabular}

Табл. 2. Порівняльний аналіз питомих показників установок для отримання МЛФ, які експлуатуються на фармацевтичних підприємствах України

\begin{tabular}{|c|c|c|c|c|c|}
\hline \multirow[b]{2}{*}{ Тип устаткування } & \multirow[b]{2}{*}{ Країна, фірма-виготовник } & \multirow{2}{*}{ 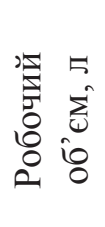 } & \multicolumn{2}{|c|}{ Середні питомі витрати } & \multirow{2}{*}{$\begin{array}{c}\text { Середня } \\
\text { питома } \\
\text { вартість, } \\
\text { у.о./л* }\end{array}$} \\
\hline & & & $\begin{array}{c}\text { енергії, } \\
\text { кВт·год./л }\end{array}$ & $\begin{array}{c}\text { металу, } \\
\text { кг/л }\end{array}$ & \\
\hline B-50L & Швейцарія, "КINEMATICA” & 50 & 0,2 & 5,0 & 5000,0 \\
\hline MACE FPA-150 B & Італія,“OLSO”' & 150 & 0,47 & 3,3 & 1920,0 \\
\hline $\mathrm{SA}-4$ & Італія, "IMA" & 800 & 0,5 & 3,5 & 1000,0 \\
\hline $\mathrm{KCA}$ & Німеччина, “LINDE”' & 12 & 0,42 & 8,3 & 4580,0 \\
\hline “Фармак” та КМ-200 & Україна, ІТТФ НАНУ & 200 & 0,09 & 3,0 & 156,0 \\
\hline БФ-320, Rigas-Farma 320 & Україна, ІТТФ НАНУ & 320 & 1,2 & 3,1 & 156,2 \\
\hline
\end{tabular}

*-розраховано за даними на 2012 р.

На фармацевтичних виробництвах в промислових масштабах випущені МЛФ широкого спектру фармакологічної дії: ранозагоючі, протиопікові, очні, протигрибкової дії, для боротьби з екзопаразитами (педикульозом) та інші препарати.

На рис. 2 представлено ряд мобільних установок та агрегатів, які легко вмонтовуються в лінії отримання різних лікарських форм. Таке устаткування добре зарекомендувало себе при отриманні складних зв'язано-дисперсних систем (концентрати, пасти, гелі, тощо) [5,6].

Установки типу КМП2 та типу «КреомаФарм» (рис. $2 a$, б) виконані з можливістю роботи також в автономному режимі, тобто можливістю здійснення комплексу технологічних операцій: термостатування, нагрів/охолодження системи, диспергування, емульгування, гомогенізація, структурування, перемішування та інші. До установок входять ємності 3 робочим об'ємом 100 л, 3 перемішучими пристроями, насосно-диспергаційний агрегат та інші допоміжні системи.

Створення дослідно-промислової установки типу «Креома-Фарм» дозволило вирішити одну 3 наукових проблем, пов'язану зі створенням комплексних методів обробки, які дозволяють одержувати необхідну наноструктуру лікарських засобів 3 прогнозованими властивостями, до яких відносяться сорбційні препарати. Значення сорбентів та ентеросорбентів у сучасній медицині велике, так як їх використовують у всіх їі напрямах: хірургії, терапії, онкології, наркології, стоматології, лікуванні захворювань шкіри та інших.

Нова форма ентеросорбенту $є$ концентро- 
ваною суспензією гідрогелю метилкремнієвої кислоти (ГГМКК) у воді. Така ЛФ відноситься до фрактальних систем, що має особливу впорядкованість - фрактальний елемент системи повторюється в різних масштабах.

ГГМКК $є$ порувата тривимірна гетероструктура, що складається 3 макро- і мікрочастинок (до $2 \cdot 10^{-2}$ м), які в свою чергу мають тонку об'ємну структуру складену 3 наночастинок
- глобул (7..15 нм), що з'єднані між собою в жорстку матрицю. На поверхні глобул просторово зшитої матриці утворюється гідратна оболонка в результаті взаємодії дисперсійного середовища (води) з поверхнею.

Проблема отримання такої ЛФ полягає в тому, що паста має складну структуру, яка визначає сорбційні властивості і залежить від умов та параметрів обробки (рис. 3 та табл. 3).

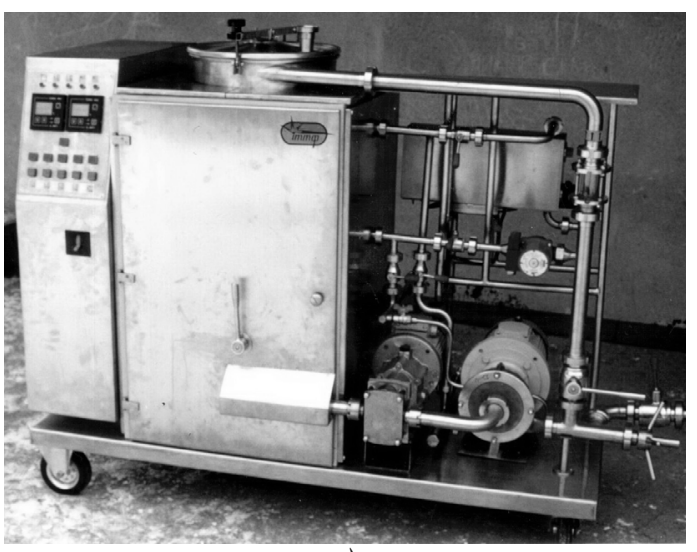

a)

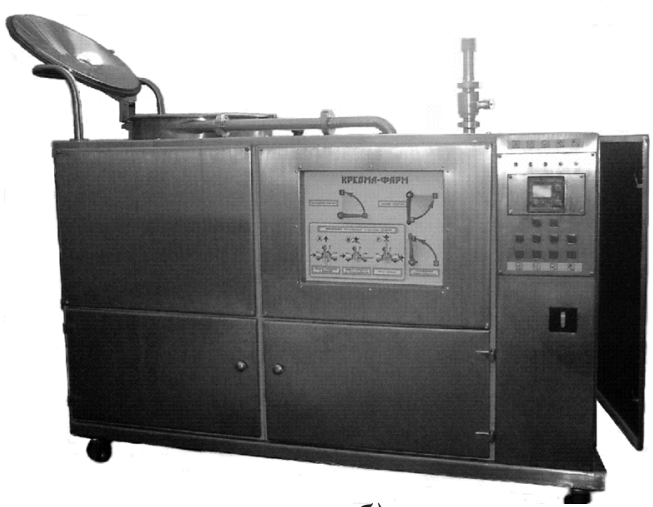

б)

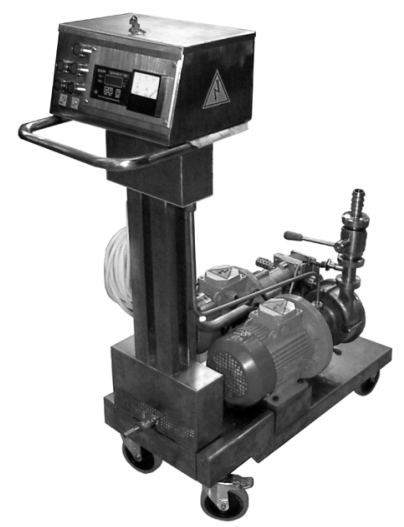

6)

Рис. 2. Модельний ряд мобільних установок для виробництва МЛФ та лікарських засобів: а) типу КМП2; б) типу «Креома-Фарм»; в) типу «Фарматрон-3000».

$\frac{d V_{s}}{d r_{e \phi}}, 10^{-3} \frac{\mathrm{M}^{3}}{\mathrm{~K} \Gamma \cdot \mathrm{HM}}$

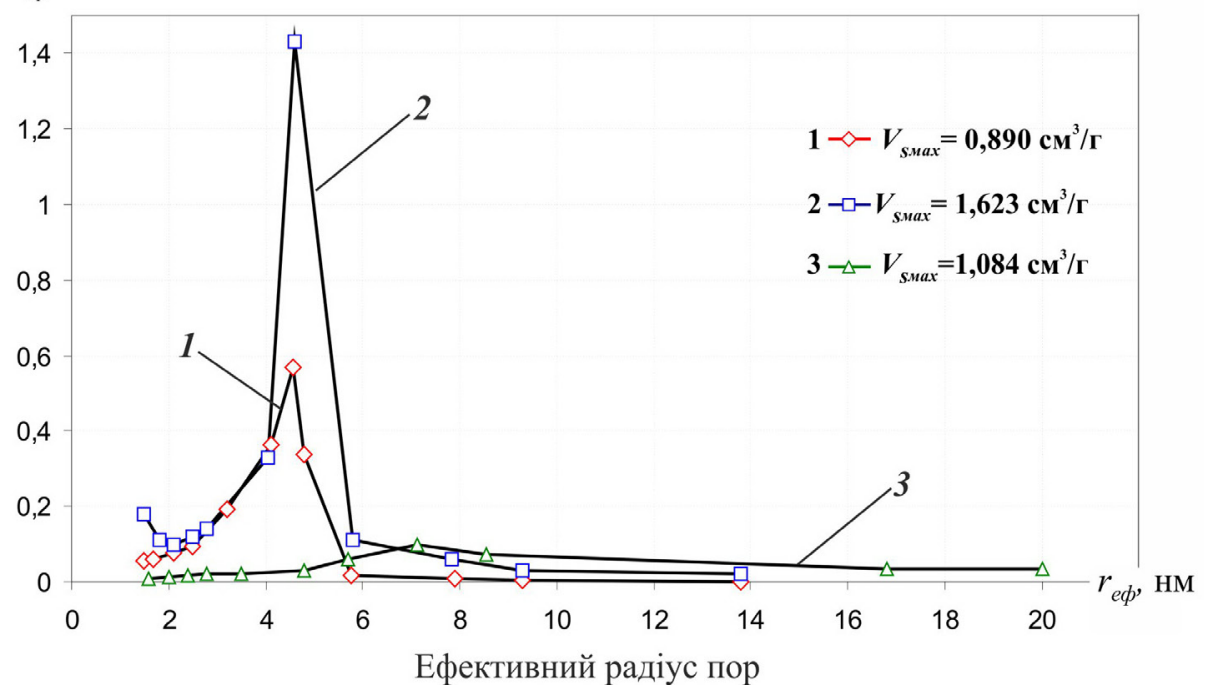

a)

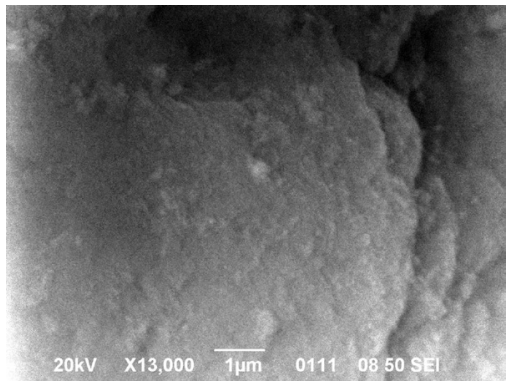

б)

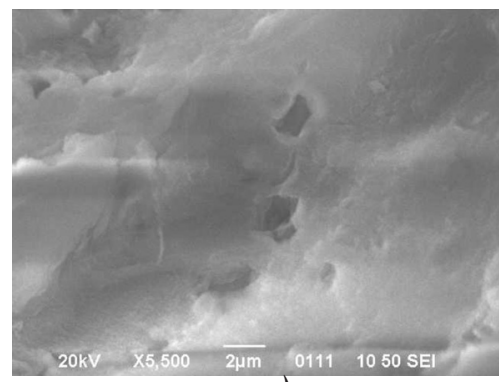

B)

Рис. 3. Криві розподілу сорбційного об'єму пор (V) за значеннями радіусів в системі “ГГМКК-вода" зі співвідноченнями компонентів 7:3 (a) та фото поверхні сорбенту: 1 - система до обробки; 2 - система після 1 циклу обробки (б); 3 - система після 10 циклів обробки (в). 
Дослідно-промислові випробування розробленої технології одержання сорбентів показали, що для отримання стійких паст гідрогелів система повинна пройти 3 етапи гідродинамічної обробки:

I - дисипативне підведення енергії до середовища, що обробляється. В об'ємі реактора завдяки роботі перемішуючого пристрою створюються невеликі градієнти швидкості, які перешкоджають седиментації гранул ГГМКК. В цей час проходить процес утворення адсорбційногідратної оболонки навколо гранул;

II - дисипативне підведення енергії в режимі циркуляції. На цьому етапі здійснюється процес руйнування слабко зв'язаних макроструктур та їх розподіл в об'ємі дисперсійного середовища;

III - дискретно-імпульсне введення енергії в циркуляційному режимі. Багатофакторний вплив на середовище в процесі гідродинамічної обробки реалізується в дисково-циліндричному апараті. На цьому етапі здійснюються остаточні фізико-хімічні процеси пов'язані з отриманням структурованих систем.

Коли дисперсна фаза - гранули ГГМКК потрапляють у дисперсійне середовище, змінюються їх фізико-хімічні властивості, так як починаються процеси гідратації та утворюються коагуляційні зв'язки між дисперсними частинками. Гідродинамічний вплив на системи з різним ступенем гідратації суттєво впливає на внутрішню наноструктуру дисперсних частинок. Це пояснюється тим, що завдяки ут воренню гідратної оболонки, а товщина іiї може досягати 4 шарів молекул води, дисперсна частинка гідрогелю набуває пружно-пластичних властивостей.

Крім того, чим глибше ступінь структурування, яка залежить від кількості циклів гідродинамічної обробки в дисковоциліндричному апараті, тим більші зсувні напруги виникають при обробці системи. За таких обставин виникають переважно пластичні деформації дисперсних частинок, що призводить до перерозподілу порового простору (рис. 3). Так у зразків поз. 1, 2 (рис. 3, a) спостерігається монорозмірний поровий простір $\left(r_{\text {eф }}=1 \ldots 14\right.$ нм $)$, а у зразка поз. 3 - діапазон пор зріс $\left(r_{\text {eф }}=1 \ldots 20\right.$ нм). Максимальний сорбційний об'єм пор $V_{\text {s }}$ більш високий у системи, яка пройшла 1 цикл обробки в дисково-циліндричному апараті, ніж у вихідної системи та системи, яка пройшла 10 циклів. За результатами досліднопромислових досліджень було встановлено, що раціональні параметри обробки системи «ГГМКК-вода» відповідають серії випробувань № 6 (табл. 3), за якими було отримано наноструктуровану пасту стійку у часі, 3 розміром дисперсних частинок 40..120 мкм, 3 найвищими сорбційними властивостями: сорбційна ємність за речовинами-моделями біомолекул (розчини конго червоного та метилоранжу) складає 3,1...3,2 мг/г, що відповідає вимогам аналітично-нормативної документації на ентеросорбційний препарат [7].

На фармацевтичних підприємствах, які в своєму арсеналі мають ємнісне обладнання, користуються попитом мобільні агрегати «Фарматрон-3000» (рис. 2, в), до складу якого входять: дисково-циліндричний апарат, насос, електротехнічна апаратура, система охолодження та контрольно-вимірювальний блок.

Завдяки застосуванню таких агрегатів вдалось вирішити проблеми отримання реологічно складних та багатокомпонентних, в т.ч. структурованих ЛФ.

Так, з використанням агрегату відпрацьовано технологію отримання комбінованого препарату антисептичної та абсцедуючої дії 3 прискоренням процесів регенерації шкіри лініменту бальзамічного (Linimentum balsamicum Wishnevsky) 3 поліпшеними властивостями (подовжується час їхньої дії та біодоступність) за рахунок додавання нанодисперсного кремнезему.

Складність процесу отримання гомогенного лініменту пов'язана 3 утворенням коагуляційних структур iз дисперсних частинок аеросілу, ксероформу та дьогтю у адгезійній основі рициновій олії (рис. 4). Процес супроводжується стрибкодібними зростяннями в'язкості системи, що призводить до підвищення температури системи. Тому технологічний процес проводиться $з$ оптимізацією температурних параметрів системи - не вище $55{ }^{\circ} \mathrm{C}$, але не нижче $30{ }^{\circ} \mathrm{C}$. 
Табл. 3. Результати відпрацювання теплотехнологічних параметрів процесів отримання ентеросорбційних паст на основі ГГМКК

\begin{tabular}{|c|c|c|c|c|c|c|c|c|c|c|c|c|c|c|}
\hline \multicolumn{8}{|c|}{ Параметры процесу обробки } & \multicolumn{7}{|c|}{ Вихідні параметри системи } \\
\hline \multicolumn{4}{|c|}{$\begin{array}{c}\text { Співвідношення дис- } \\
\text { персна фаза: дисп. } \\
\text { середовище }\end{array}$} & \multicolumn{2}{|c|}{$\begin{array}{c}\text { Питома } \\
\text { трива- } \\
\text { лість, хв./кг }\end{array}$} & \multirow{3}{*}{ 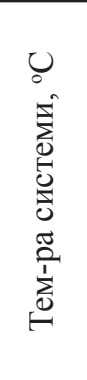 } & \multirow{3}{*}{ 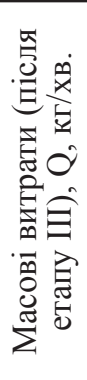 } & \multirow{3}{*}{$\begin{array}{c}\text { Розміри } \\
\text { дисперсн. } \\
\text { мікро- } \\
\text { частинок, } \\
\text { мкм } \\
\text { основна } \\
\text { маса } \\
\text { (макс.) }\end{array}$} & \multirow{3}{*}{$\begin{array}{c}\text { Су- } \\
\text { хий } \\
\text { зали- } \\
\text { шок, } \\
\%\end{array}$} & \multicolumn{2}{|c|}{$\begin{array}{c}\text { Сорбційна } \\
\text { ємність за } \\
\text { речовинами- } \\
\text { моделями } \\
\text { біомолекул, } \\
\text { мг/г } \\
\end{array}$} & \multicolumn{3}{|c|}{$\begin{array}{c}\text { Агрегативна та кінетична } \\
\text { стійкість систем }\end{array}$} \\
\hline \multirow[b]{2}{*}{$\begin{array}{l}\text { № } \\
3 / \Pi\end{array}$} & \multicolumn{5}{|c|}{ Етапи } & & & & & & & струк- & & \\
\hline & I & \begin{tabular}{l|l|} 
II & III
\end{tabular} & I & II & III & & & & & $\begin{array}{l}\text { го } \\
\text { чер- } \\
\text { воний }\end{array}$ & $\begin{array}{l}\text { тил- } \\
\text { оранж }\end{array}$ & $\begin{array}{l}\text { туро- } \\
\text { утво- } \\
\text { рення }\end{array}$ & $\begin{array}{c}\text { седимен- } \\
\text { тація }\end{array}$ & $\begin{array}{l}\text { віднов- } \\
\text { лення }\end{array}$ \\
\hline 1 & $4: 1$ & $2,6: 1$ & 0,25 & 1,5 & 0,1 & $\begin{array}{c}10 \ldots \\
14\end{array}$ & 9,8 & $\begin{array}{l}60 \ldots 200 \\
\text { (до } 300)\end{array}$ & 6,81 & 2,8 & 2,9 & плинна & $\begin{array}{c}\text { незначне } \\
\text { розша- } \\
\text { рування }\end{array}$ & має \\
\hline 2 & $3: 1$ & $2,6: 1$ & 0,25 & 1,15 & 0,15 & $\begin{array}{c}12 \ldots \\
35\end{array}$ & 6,5 & $\begin{array}{l}40 \ldots 160 \\
\text { (до } 300)\end{array}$ & 6,55 & 2,7 & 2,7 & рухома & стійка & $\begin{array}{c}\text { віднов- } \\
\text { лення } \\
\text { ч/3 } \\
2 \text { год. }\end{array}$ \\
\hline 3 & $4: 1$ & $2,3: 1$ & 0,25 & 1,5 & 0,1 & $\begin{array}{c}14 \ldots \\
30\end{array}$ & 1,7 & $\begin{array}{l}40 \ldots 120 \\
\text { (до } 300)\end{array}$ & 6,83 & 2,9 & 3,0 & $\begin{array}{c}\text { формо- } \\
\text { утрим. } \\
\text { плас- } \\
\text { тична }\end{array}$ & $\begin{array}{c}\text { незначне } \\
\text { розша- } \\
\text { рування }\end{array}$ & має \\
\hline 4 & $4: 1$ & $2,3: 1$ & 0,5 & 0,125 & 0,45 & $\begin{array}{c}16 \ldots \\
35\end{array}$ & 1,4 & $\begin{array}{l}60 \ldots 140 \\
\text { (до 300) }\end{array}$ & 6,7 & 2,7 & 2,9 & $\begin{array}{c}\text { формо- } \\
\text { утрим. } \\
\text { плас- } \\
\text { тична }\end{array}$ & стійка & має \\
\hline 5 & \multicolumn{2}{|c|}{$2,4: 1$} & 0,15 & 0,24 & 0,1 & $\begin{array}{c}13 \ldots \\
16\end{array}$ & 17 & $\begin{array}{l}60 \ldots 100 \\
\text { (до 200) }\end{array}$ & & 2,8 & 2,5 & плинна & нестійка & не має \\
\hline 6 & $4: 1$ & $2,3: 1$ & 0,25 & 1,5 & 0,01 & $\begin{array}{c}17 \ldots \\
20\end{array}$ & 5,1 & $\begin{array}{l}40 \ldots 120 \\
\text { (до 250) }\end{array}$ & 7,81 & 3,2 & 3,1 & $\begin{array}{c}\text { рухома } \\
\text { плас- } \\
\text { тична }\end{array}$ & стійка & має \\
\hline 7 & $3,7: 1$ & $2,7: 1$ & 0,35 & 1,5 & 0,75 & $\begin{array}{c}16 \ldots \\
18\end{array}$ & 5,7 & $\begin{array}{l}60 \ldots 150 \\
\text { (до 250) }\end{array}$ & 7,63 & 2,8 & 2,8 & $\begin{array}{c}\text { формо- } \\
\text { утрим. } \\
\text { плас- } \\
\text { тична } \\
\end{array}$ & $\begin{array}{c}\text { незначне } \\
\text { розша- } \\
\text { рування }\end{array}$ & має \\
\hline 8 & $4: 1$ & $1,9: 1$ & 0,3 & 0,6 & 0,5 & $\begin{array}{c}17 \ldots \\
19\end{array}$ & 4,5 & $\begin{array}{l}40 \ldots 160 \\
\text { (до } 300 \text { ) }\end{array}$ & 7,48 & 3,0 & 2,8 & $\begin{array}{l}\text { формо- } \\
\text { утрим. }\end{array}$ & $\begin{array}{c}\text { незначне } \\
\text { розша- } \\
\text { рування }\end{array}$ & має \\
\hline 9 & & $3: 1$ & 0,15 & 0,23 & 0,09 & $\begin{array}{c}15 \ldots \\
18\end{array}$ & 11,5 & $\begin{array}{l}60 \ldots 260 \\
\text { (до 350) }\end{array}$ & 6,29 & 2,6 & 2,7 & плинна & нестійка & не має \\
\hline 10 & & $4: 1$ & 0,15 & 0,59 & 0,07 & $\begin{array}{c}13 \ldots \\
19\end{array}$ & 13,7 & $\begin{array}{l}50 \ldots 200 \\
(\text { до 300) }\end{array}$ & 6,3 & 2,6 & 2,7 & плинна & нестійка & не має \\
\hline
\end{tabular}

В даний час багато провідних виробників лікарських засобів віддають перевагу випуску МЛФ у вигляді гелю. Традиційно технологічний процес отримання $є$ періодичним та багатоступеневим: попереднє подрібнення на колоїдних млинах, просіювання субстанцій як основних так і допоміжних, приготування концентрованих суспензій або емульсій з лікарськими речовинами, приготування основи-носія і введення лікарських речовин в основу в реакторах-гомогенізаторах та транспортування готового продукту на фасування з залученням допоміжного обладнання 
(занурений насос). Причому, однією iз відповідальних стадій є приготування основиносія, так як вона забезпечує оптимальну консистенцію і є важливим чинником, що впливає на повноту і швидкість вивільнення та всмоктування лікарських речовин.

Для створення основ гелів на даний час віддається перевага таким структуроутворювачам, як карбомери: для отримання ЛФ з в'язкістю 0,8 Па·с (при $20{ }^{\circ} \mathrm{C}$ ) необхідно до 0,2 \% карбомеру, тоді як інших - 1..6,5 \%. Проблемою застосування порошку карбомеру є його введення в рідину за допомогою просіювача, створення в потоці рідини в реакторі-гомогенізаторі так званої «воронки» та чіткий контроль за температурою, водневим показником, гідродинамічними параметрами потоку рідини протягом процесу структуроутворення, який включає послідовність процесів перемішування, змочування, набухання, гідратації, нейтралізації.

Завдяки використанню агрегату «Фарматрон-3000» в лінії отримання спиртових гелів ліквідовано ряд стадій (попереднє подрібнення), вдалося мінімізувати використання ручної роботи (введення структуроутворювача в рідину) та відмовитись від залучення додаткового обладнання (колоїдний млин, занурений насос), що дозволило поряд з поліпшенням якості продукту (досягнута структурна однорідність) скоротити тривалість процесу отримання у 2 рази [8].

Спиртовий гель, який отримано за запропонованою технологією з використанням агрегату "Фарматрон-3000", є системою 3 вираженими псевдопластичними реологічними властивостями, що свідчить про одержання структурованої системи. При низьких напругах зсуву гель не має плинності, при високих зсувних напругах (до 2...2,5 МПа), які розвиваються в дисковоциліндричному апараті в процесі гідродинамічної обробки, він стає плинним. Короткочасний вплив таких напруг не приводить до незворотних руйнувань його просторової структури - оброблена система має тиксотропні властивості.

В'язкість отриманого спиртового гелю досягає $6,5 \pm 1,5$ Па·с, а оптична густина $1,366 \pm 0,003$, що відповідає аналітичнонормативній документації на готовий продукт.

Лікарський засіб AHD-2000 гель має бактерицидні та туберкулоцидні властивості, інактивує віруси, у т.ч. ВІЛ-інфекцію, гепатит, знижує кількість транзитної мікрофлори шкіри за 30 с в 100 тис. разів. Препарат застосовується для антисептики у всіх галузях медицини. Крім того, його застосування буде корисним в польових умовах та в хірургічних відділеннях шпиталів.

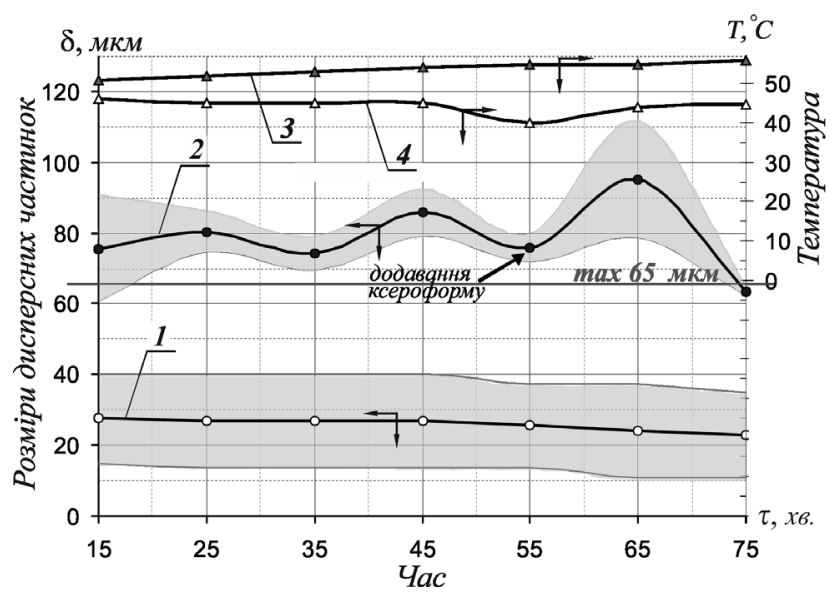

Рис. 4. Кінетика процесів диспергування, структурування та гомогенізації при отриманні лініменту бальзамічного (за Вишневським): 1 - основна маса коагуляційних частинок (за ФС дозволяється до 65 мкм); 2 - коагуляційні частинки максимального розміру (за ФС-частинки 65-100 мкм у 10 полях зору); 3 - температура продукту; 4 - температура теплоносія в системі охолодження дисково-циліндричного апарату. 
Табл. 4. Основні технічні характеристики дисково-циліндричних апаратів

\begin{tabular}{|c|c|c|c|c|c|c|c|c|c|}
\hline \multirow[b]{2}{*}{ Тип апарата } & \multirow[b]{2}{*}{ 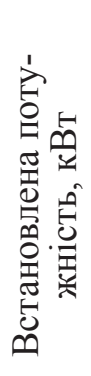 } & \multirow[b]{2}{*}{ 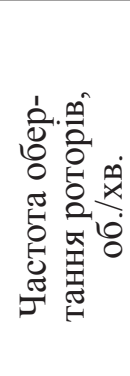 } & \multirow[b]{2}{*}{ 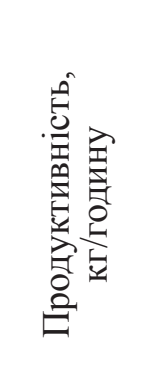 } & \multicolumn{3}{|c|}{ Дисковий вузол } & \multicolumn{3}{|c|}{ Циліндричний вузол } \\
\hline & & & & статор & ротор & $\begin{array}{c}\text { «криль- } \\
\text { чатка» }\end{array}$ & 罾 & 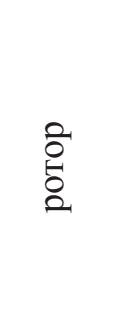 & 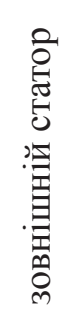 \\
\hline $\begin{array}{l}\text { РПГ-2500 } \\
\text { (рис. 5, а) }\end{array}$ & 2,2 & 2860 & до 2500 & \multicolumn{3}{|c|}{-} & \multicolumn{3}{|c|}{$\begin{array}{c}\text { середній діаметр } \\
d_{\text {cp }}-118 \text { мм, } \\
72 \text { прорізи на } \\
\text { кожному елементі } \\
\end{array}$} \\
\hline AP-1000 & 1,5 & 2850 & до 1000 & \multicolumn{2}{|c|}{$\begin{array}{l}\text { перфорація: } 106 \\
\text { каналів Ø 2,0 мм }\end{array}$} & $\begin{array}{c}18 \text { пазів по } \\
2 \mathrm{Mm} ; d_{\mathrm{cp}}-78 \mathrm{мм}\end{array}$ & \multicolumn{3}{|c|}{$\begin{array}{c}d_{c p}-98 \text { мм, } \\
36 \text { пазів } 2 \times 20 \text { на } \\
\text { кожному елементі }\end{array}$} \\
\hline $\begin{array}{l}\text { AР-3000 } \\
\text { (рис. 5, б) }\end{array}$ & 3 & 2880 & до 3000 & \multicolumn{2}{|c|}{$\begin{array}{l}\text { перфорація: } 192 \\
\text { каналів Ø 2,5 мм }\end{array}$} & - & \multicolumn{3}{|c|}{$\begin{array}{c}d_{\mathrm{cp}}-120 \mathrm{мм}, \\
72 \text { прорізи по } 1,4 \times 7 \mathrm{Mм} \\
\text { на кожному елементі }\end{array}$} \\
\hline $\begin{array}{l}\text { ДЦД (рис. 5, в) } \\
\text { базова модифі- } \\
\text { кація М }\end{array}$ & \multirow{4}{*}{4} & \multirow{4}{*}{2880} & до 4000 & \multirow{3}{*}{\multicolumn{2}{|c|}{$\begin{array}{c}\text { перфорація: } 180 \\
\text { каналів Ø } 3,0 \text { мм, } \\
36 \text { - Ø 2,5 мм }\end{array}$}} & $\begin{array}{c}36 \text { пазів по } \\
3 \text { мм; } d_{\text {ср }}-98 \text { мм }\end{array}$ & \multicolumn{3}{|c|}{$\begin{array}{c}d_{\text {cp- }}-118 \text { мм, } \\
72 \text { прорізи по } 2 \times 20 \text { мм } \\
\text { на кожному елементі }\end{array}$} \\
\hline модифікація М1 & & & до 3500 & & & - & \multicolumn{3}{|c|}{$\begin{array}{c}d_{c p}-118 \text { мм, } \\
72 \text { прорізи по } 2 \times 20 \text { мм } \\
\text { на кожному елементі }\end{array}$} \\
\hline модифікація М2 & & & до 4000 & & & $\begin{array}{c}36 \text { пазів по } \\
3 \text { мм; } d_{\mathrm{cp}}-98 \text { мм }\end{array}$ & \multicolumn{3}{|c|}{$\begin{array}{c}d_{\mathrm{cp}}-118 \text { мм, } \\
72 \text { пази по } 2 \times 20 \text { мм } \\
\text { на кожному елементі }\end{array}$} \\
\hline модифікація М3 & & & до 3800 & \multicolumn{2}{|c|}{-} & 3 лопаті & \multicolumn{3}{|c|}{$\begin{array}{c}d_{\mathrm{cp}}-118 \text { мм, } \\
72 \text { щілини по } 2 \times 20 \text { мм } \\
\text { на кожному елементі }\end{array}$} \\
\hline $\begin{array}{l}\text { ДВ-5,5 } \\
\text { (рис. 5, г) }\end{array}$ & 5,5 & 3000 & до 5000 & $\begin{array}{l}216 \text { кана- } \\
\text { лів Ø } 3 \text { мм }\end{array}$ & $\begin{array}{l}\text { радіальні } \\
\text { прорізи } \\
38 \times 2,5 \mathrm{Mм}\end{array}$ & $\begin{array}{l}24 \text { пази по } \\
3 \text { мм; } d_{\mathrm{cp}}- \\
136 \mathrm{мм}\end{array}$ & \multicolumn{3}{|c|}{$\begin{array}{c}d_{\text {cp. }}-177 \text { мм, } \\
80 \text { пазів по } 3 \times 30 \text { мм } \\
\text { на кожному елементі }\end{array}$} \\
\hline $\begin{array}{l}\text { ЛДЦД-750 } \\
\text { (рис. 5, д) }\end{array}$ & 0,75 & $\begin{array}{l}3000 \ldots \\
10000\end{array}$ & до 50 & \multicolumn{2}{|c|}{$\begin{array}{c}\text { перфорація: череду- } \\
\text { вання } 12 \text { каналів } \\
\varnothing 2,0 \text { мм та } 12 \\
\text { радіальних прорізів } \\
2 \times 6 \text { мм }\end{array}$} & $\begin{array}{c}24 \text { пази по } \\
3 \text { мм; } d_{\mathrm{cp}}-34 \text { мм }\end{array}$ & \multicolumn{2}{|c|}{$\begin{array}{c}d_{\text {cp }}-40 \text { мм, } \\
24 \text { пази } 2 \times 7 \text { мм } \\
\text { на кожному } \\
\text { елементі }\end{array}$} & - \\
\hline
\end{tabular}

Найбільш відповідальними процесами при отриманні МЛФє диспергування та гомогенізація, від яких залежить якість готового продукту, що суворо регламентується фармацевтичними нормами. Крім того, процеси подрібнення та диспергування $€$ енергоємними: на здійснення цього процесу витрачається від 8 \% до 20 \% від енергії, що виробляється в світі [9]. Тому суттєву увагу в ІТТФ НАНУ приділено розробці апаратів для здійснення та інтенсифікації процесів диспергування та гомогенізації в гетерогенних середовищах [10,11]. Базовими елементами дисково-циліндричних апаратів роторнопульсаційного типу $є$ : дисковий вузол - 
конструкція 3 двох перфорованих дисків, один 3 яких обертається, i циліндричний вузол конструкція 3 трьох або чотирьох коаксіальних циліндричних обичайок з прорізами або пазами, одна або дві з яких обертаються. У ряді моделей на дисковому роторі розташована так звана «крильчатка», що являє собою циліндричну обичайку зі специфічними пазами (рис. 5 та табл. 4).

Вибір моделі апарату залежить від фізикохімічних властивостей системи та комплексу теплофізичних процесів, які обумовлені технологічними регламентами.

Здійснення технологічних процесів в апаратах реалізується за рахунок комплексу фізичних явищ: трансформація потенційної енергії в кінетичну, механізми зсуву та зрізу, кавітація, акустичні коливання, мікрозакипання, поляризація частинок, миттєвий локальний нагрів та інші механізми дискретно-імпульсного введення енергії (ДІВЕ) в гетерогенні середовища. Величина та тривалість гідродинамічних збурень потоку рідини та температурні градієнти в середовищах, що обробляються в таких апара- тах, залежить в т.ч. від технічних та конструктивних характеристик апаратів (табл. 4).

Вперше завдяки впровадженню апарата АР-3000 у лінію отримання супозиторних ЛФ вдалося вирішити проблему отримання стабільних дифільних систем, тобто систем 3 гідрофобним дисперсійним середовищем 3 рівномірно розподіленою в ньому гідрофільною дисперсною фазою.

Для вдосконалення технології отримання, встановлення оптимальних теплотехнологічних параметрів та покращення якості суспензійних ЛФ проведено комплекс експериментальних досліджень процесів диспергування частинок в системі «тверда фаза - рідина». Фармакопейні статті (регламенти) та аналітично-нормативна документація, які поширюються на виробництво таких препаратів, вимагають обмеження максимальних розмірів дисперсних частинок лікуючих речовин, тому що їх розмір впливає на швидкість і повноту всмоктування в організм людини при застосуванні фармацевтичних препаратів.

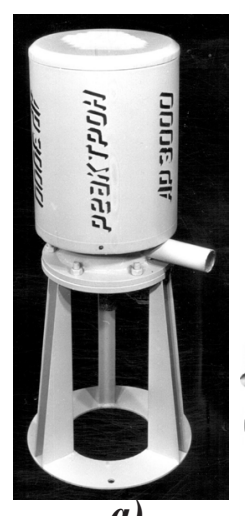

a)

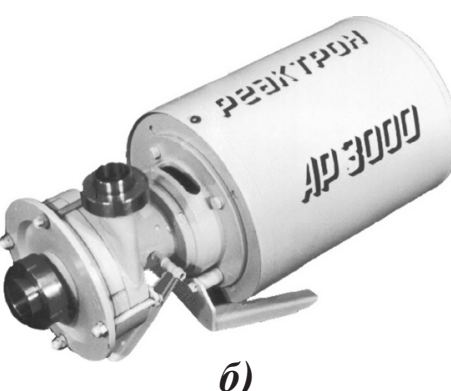

б)

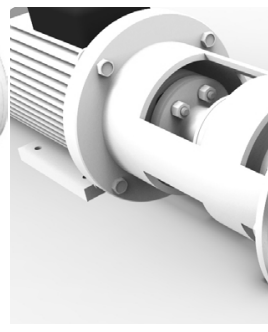

(a)

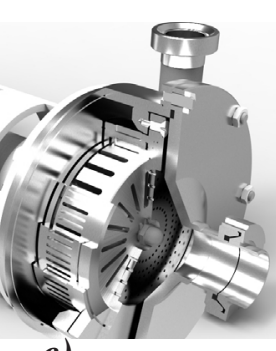

в)

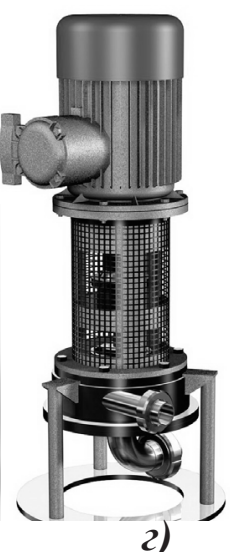

2)

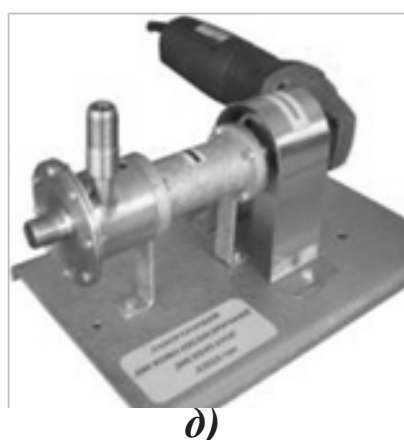

d)

фізико-хімічних та тепломасообмінних процесів в технології виробництва ЛФ:

а) anapam РПГ-2500; б) АР-3000; в) ДЦД; г) ДВ-5,5; д) ЛДЦД-750.

Аналіз результатів досліджень (табл. 5) показав, що для інтенсифікації та оптимізації процесу диспергування необхідно враховувати низку факторів: дисперсний склад вихідних субстанцій та співвідношення компонентів гетерогенної системи, початкову температуру системи, іiі швидкість та структурно-механічні властивості, як твердих субстанцій так i дисперсійного середовища (основ-носіїв).
Важливою стадією отримання мазевих та супозиторних ЛФ є підготовка основи-носія. Переважно основа представляє суміш вуглеводневих речовин з різними теплофізичними властивостями. Особливості полягають в наступному: досить висока температура переходу основи в розплав, або температура плавлення, що коливається в широкому діапазоні $\left(27 \ldots 70{ }^{\circ} \mathrm{C}\right)$, схильність до термодеструкції 
та низький коефіцієнт теплопровідності Такі методи $є$ тривалими та енергоємними, $(0,025 \ldots 0,37$ кВт/(м·К)).

Традиційно на фармацевтичних підприємствах процеси нагрівання та плавлення таких основ-носіїв здійснюють у електрокотлах, котлах 3 паровою сорочкою, в термокамерах та за допомогою, так званих, електропоясів. спостерігаються великі градієнти температури, що найчастіше призводить до перегріву однієї частини та недогріву іншої. Крім того, проблематичним і контамінаційно небезпечним $\epsilon$ процес завантаження основи в котли та вивантаження розплаву 3 них.

Табл. 5. Результати досліджень процесу диспергування твердих субстанцій у рідинному середовищі

\begin{tabular}{|c|c|c|c|c|c|c|c|c|}
\hline $\begin{array}{l}\text { Параметр } \\
\text { варіювання }\end{array}$ & 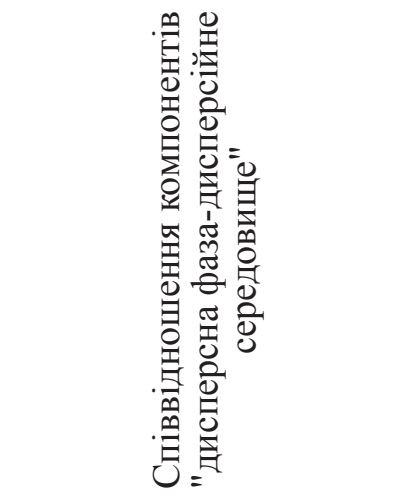 & 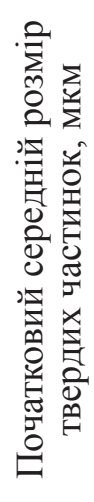 & 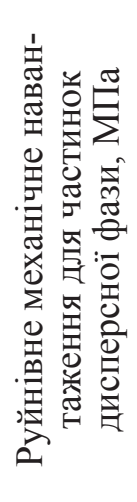 & 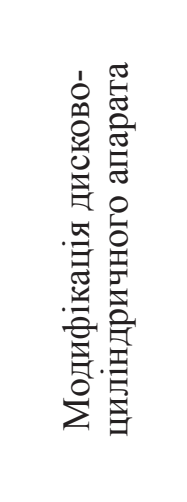 & $\begin{array}{l}0 \\
0 \\
0 \\
0 \\
0 \\
0 \\
0 \\
0 \\
0 \\
0 \\
0 \\
0 \\
0 \\
0 \\
0 \\
0 \\
0 \\
0 \\
0 \\
0 \\
0\end{array}$ & 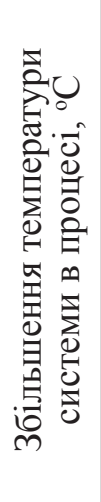 & 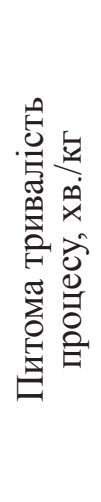 & 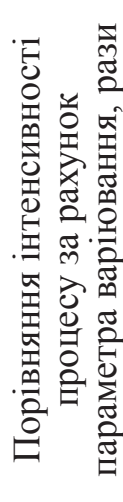 \\
\hline 1 & 2 & 3 & 4 & 5 & 6 & 7 & 8 & 9 \\
\hline \multirow{2}{*}{$\begin{array}{c}\text { Співводнешення ком- } \\
\text { понентів системи }\end{array}$} & $\begin{array}{c}\text { "саліцилова кислота- } \\
\text { вазелін" } 1: 2,4\end{array}$ & \multirow[t]{2}{*}{500} & \multirow{2}{*}{$\begin{array}{c}2,13 \ldots \\
3,87\end{array}$} & \multirow{2}{*}{ ДЦД M2 } & 55 & 6 & 4,8 & \multirow[t]{2}{*}{2,8} \\
\hline & $1: 3,3$ & & & & 55 & 4 & 12,4 & \\
\hline \multirow{2}{*}{$\begin{array}{c}\text { Початковий середній } \\
\text { розмір твердих } \\
\text { частинок, мкм } \\
\end{array}$} & \multirow{2}{*}{$\begin{array}{c}\text { "саліцилова кислота- } \\
\text { вазелін" 1:3,5 }\end{array}$} & 390 & \multirow{2}{*}{$\begin{array}{c}2,13 \ldots \\
3,87\end{array}$} & \multirow{2}{*}{ ДШД M2 } & 55 & 4 & 3,1 & \multirow{2}{*}{1,5} \\
\hline & & 560 & & & 55 & 4 & 5 & \\
\hline \multirow{4}{*}{$\begin{array}{c}\text { Руйнівне механічне } \\
\text { навантаження для } \\
\text { твердих частинок, } \\
\text { МПа }\end{array}$} & $\begin{array}{c}\text { "саліцилова кислота- } \\
\text { вазелін" } 1: 2\end{array}$ & \multirow{2}{*}{410} & $\begin{array}{c}2,13 \ldots \\
3,87\end{array}$ & \multirow{2}{*}{ ДЦД М2 } & 55 & 4 & 12,3 & \multirow{2}{*}{7,2} \\
\hline & $\begin{array}{c}\text { "метилурацил- } \\
\text { вазелін" 1:2 }\end{array}$ & & $\begin{array}{c}0,97 \ldots \\
2,42 \\
\end{array}$ & & 42 & 2 & 1,7 & \\
\hline & $\begin{array}{c}\text { "саліцилова кислота- } \\
\text { вазелін" 1:3 }\end{array}$ & 150 & $\begin{array}{c}2,13 \ldots \\
3,87 \\
\end{array}$ & & 55 & 4 & 0,8 & 6 \\
\hline & $\begin{array}{l}\text { "стрептоцид- } \\
\text { вазелін" 1:3 }\end{array}$ & 450 & $\begin{array}{l}2,7 \ldots \\
5,32\end{array}$ & ДЦд ML & 45 & 7 & 4,8 & 0 \\
\hline \multirow{3}{*}{$\begin{array}{c}\text { Початкова температура } \\
\text { системи, }{ }^{\circ} \mathrm{C}\end{array}$} & \multirow{3}{*}{$\begin{array}{c}\text { "анестезін- } \\
\text { гліцерин" } \\
\text { 1:6 }\end{array}$} & \multirow{3}{*}{850} & \multirow{3}{*}{$\leq 0,9$} & \multirow{3}{*}{ AP-1000 } & 16 & 24 & 4,2 & \multirow{3}{*}{$\begin{array}{c}1,3 \ldots \\
2\end{array}$} \\
\hline & & & & & 20 & 32 & 5,5 & \\
\hline & & & & & 30 & 32 & 8,5 & \\
\hline \multirow{4}{*}{$\begin{array}{c}\text { Модифікація дисково- } \\
\text { циліндричних апаратів } \\
\text { (табл. 4) }\end{array}$} & \multirow{2}{*}{$\begin{array}{c}\text { "саліцилова кислота- } \\
\text { вазелін" 1:2,5 }\end{array}$} & \multirow{2}{*}{500} & \multirow{2}{*}{$\begin{array}{c}2,13 \ldots \\
3,87\end{array}$} & ДЦД М1 & 55 & 10 & 6,4 & \multirow{2}{*}{2} \\
\hline & & & & ДЦД M2 & 55 & 4 & 12,4 & \\
\hline & \multirow{2}{*}{$\begin{array}{l}\text { "стрептоцид- } \\
\text { вазелін" 1:3 }\end{array}$} & \multirow{2}{*}{450} & \multirow{2}{*}{$\begin{array}{l}2,7 \ldots \\
5,32\end{array}$} & ДЦД М2 & 48 & 22 & 4,8 & \multirow{2}{*}{2,5} \\
\hline & & & & ДЦД М3 & 45 & 7 & 0,8 & \\
\hline
\end{tabular}


Вирішення цих проблем запропоновано фахівцями ІТТФ НАНУ за рахунок впровадження нового методу термоконтактного плавлення, який реалізується в установках типу "Термобат" 3 можливістю плавлення основ в металевій тарі завода-виробника (рис. 6).

Сутність метода термоконтактного плавлення основ полягає в наступному. Сталевий диск, який нагрівається за рахунок циркуляції теплоносія, контактує 3 твердою основою. У процесі плавлення він опускається під дією власної ваги до нерозплавленого шару. Розплав насосом транспортується до реакторів, де здійснюються наступні стадії отримання МЛФ [12].

При вирішенні проблеми інтенсифікації міжфазових переходів для субстанцій 3 підвищеною температурою плавлення був запропонований алгоритм, що дозволив оптимізувати теплотехнологічні параметри (швидкість плавлення та охолодження різних

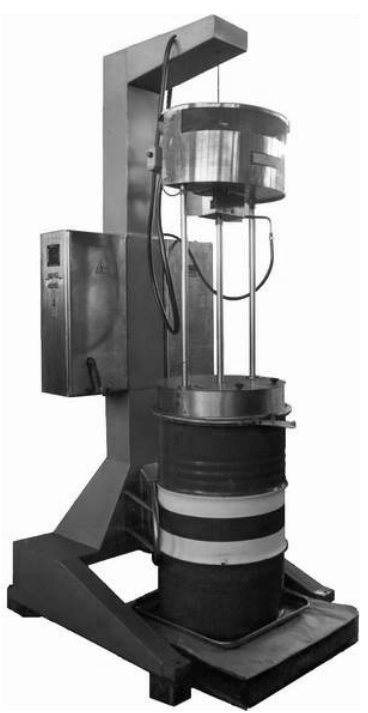

a)

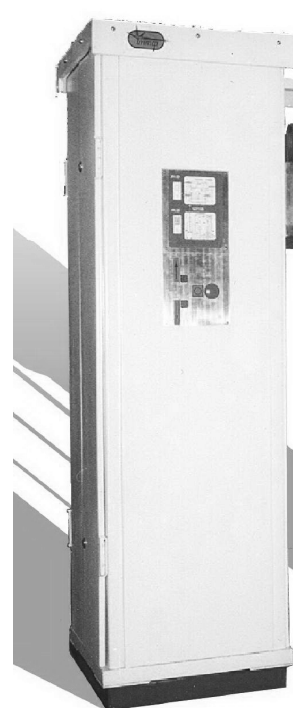

Рис. 6. Модельний ряд установок

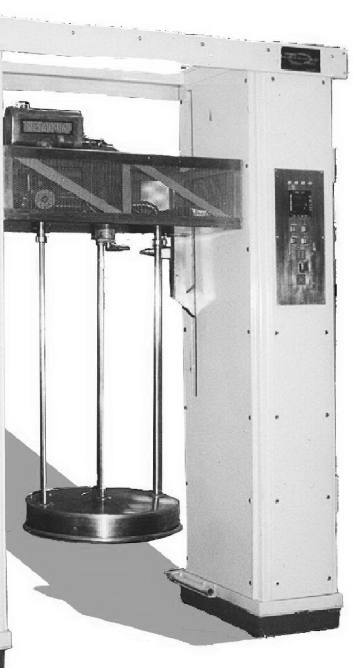

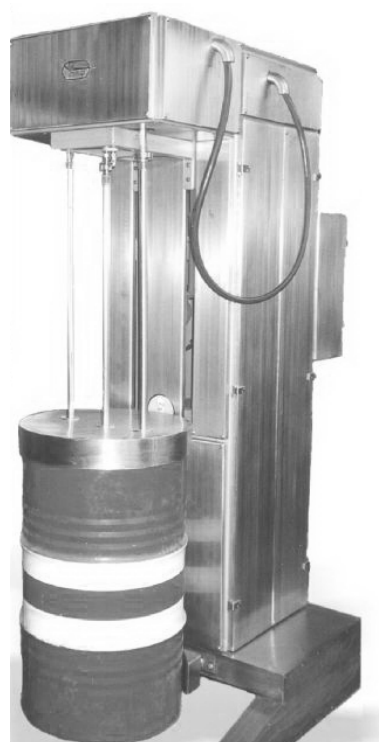

в)

основ, в т.ч. гетерогенних, товщину шару розплаву під термодиском, поля температур в розплаві та твердій субстанції, швидкість, з якою опускається диск), а також визначити енерговитрати (табл. 6).

Експериментально встановлено оптимальні параметри процесів плавлення для різних основ-носіїв. Так, температури теплоносія $68 . .71{ }^{\circ} \mathrm{C}$ для плавлення фармацевтичного вазеліну MERKUR-500 недостатньо, так як в процесі транспортування він застигає у трубопроводі. А вже при досягненні 79...80 ${ }^{\circ} \mathrm{C}$ основа стає достатньо плинною, що забезпечує можливість ії перекачування.

Дослідно-промислові випробування показали, що питомі витрати енергії при застосуванні установок термоконтактного плавлення основносіїв в 4...5 разів менші, ніж традиційного діючого устаткування [13]. а) «Термобат-4,5»; б) «Термобат-4,5Ф»; в) «Термобат-9»; г) «Термобат-М».

\section{Висновки}

1. Фахівцями ІТТФ НАНУ розроблено та виготовлено більше тридцяти десятків одиниць фармацевтичного обладнання, в т.ч. установок для отримання м'яких лікарських форм (МЛФ), мобільних насосно-диспергаційних агрегатів, дисково-циліндричних апаратів для гомогенізації та диспергування, установки для нагрівання та плавлення основ-носіїв. Тепломасообмінне об- ладнання та апарати для диспергування успішно працюють на підприємствах України та за кордоHOM.

2. На впровадженому обладнанні в лініях отримання різних лікарських форм (близько 65 найменувань) 3 широким спектром фармакологічної дії випущено більше 100 млн. упаковок мазей, гелів, лініментів, паст, кремів, аерозольних та супозиторних форм. 
Табл. 6. Техніко-технологічні характеристики установок термоконтактного плавлення основ

\begin{tabular}{|c|c|c|c|c|c|c|}
\hline $\begin{array}{l}\text { № } \\
\text { 3/ח }\end{array}$ & Тип устаткування & 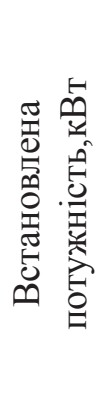 & 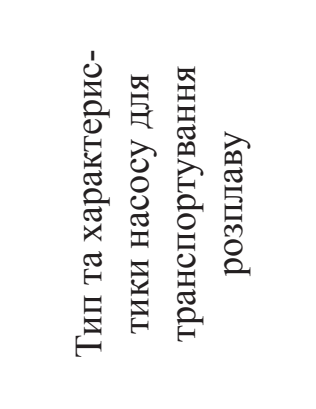 & 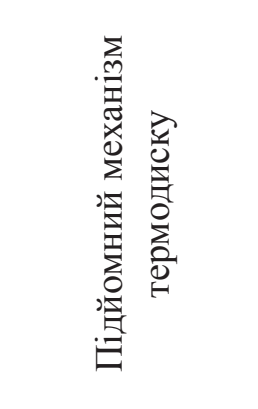 & 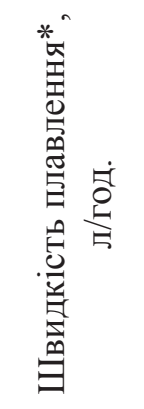 & 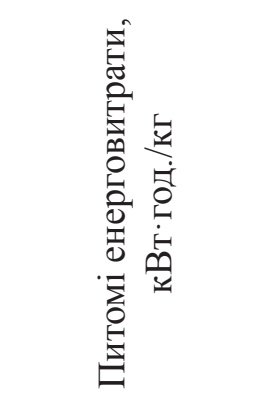 \\
\hline 1. & «Термобат-4,5» (рис. 6, $a$ ) & 4,5 & шестерінчастий & ручний & \multirow{2}{*}{$35 \ldots 75$} & \multirow{2}{*}{$0,045 \ldots 0,075$} \\
\hline 2. & «Термобат-4,5Ф» (рис. 6, б) & 8,1 & шестерінчастий & гідравлічний & & \\
\hline 3. & «Термобат-9» (рис. 6, в) & 9,6 & шестерінчастий & ручний & \multirow{2}{*}{$55 \ldots 95$} & \multirow{2}{*}{$0,016 \ldots 0,027$} \\
\hline 4. & «Термобат-М» (рис. 6, г) & 12 & гвинтовий & ручний & & \\
\hline
\end{tabular}

\section{ЛІТЕРАТУРА}

1. Дранік Л.І. Досягнення та проблеми в області створення м'яких лікарських форм // Фармаком. - 1994, № 4. - С. 17 - 19.

2. Козлова Н.Г. Некоторые особенности создания лекарственных средств в форме суппозиториев/ Козлова Н.Г., Замараева Е.Е., Драник Л.И. // Фармация. - 1992, Т. 41, № 6. С. $80-83$.

3. Державна Фармакопея України / Державне підприємство «Науково-експертний фармакопейний центр. - 1-е вид. - Х.: РІРЕГ, 2001. $556 \mathrm{c}$.

4. Долінський А.А. Принцип ДІВЕ та його використання у технологічних процесах. - К.: Наукова думка, $2001-346$ с.

5. Долинский А.А. Метод ДИВЭ в инновационных технологиях и тепломассообменном оборудовании / А.А. Долинский, Л.Н. Грабов, Т.Л. Грабова // Промышленная теплотехника. - 2012. - T. 34, № 3. - C. 18-30.

6. Патент 55709 UA, МПК В01F 7/16, В01F 3/08. Спосіб гідродинамічної обробки гетерогенних рідких середовищ та гідродинамічний диспергатор-змішувач для його здійснення / Л.М. Грабов, В.І. Мерщій, Т.Л. Грабова.; заявник и патентовласник ІТТФ НАНУ. - №2002053954; опубл. 16.01.06, Бюл. №1.

7. Долінський А.А. Теплофізичні методи створення наноструктурованих матеріалів 3 покра- щеними властивостями / А.А. Долінський, Л.М. Грабов та інші // Промышленная теплотехника. -2010 . - Т. 32, № 6. - С. 5-14.

8. Грабова Т.Л. Отримання гелевих систем методом гідродинамічної обробки // Наукові праці ОНАХТ. - 2010 - вип. 37. - С. 330-334.

9. Пилов П.И. Моделирование замкнутых циклов измельчения на основе гипотезы Риттингера / П.И. Пилов, Н.С. Прядко // Збагачення корисних копалин. - 2012. - Вып. 51(92). - С. 92-102.

10. Патент 59460 UA, МПК В01F 7/26. Спосіб субмікронного диспергування багатокомпонентних рідких середовищ і пристрій для його здійснення / Долінський А.А., Грабов Л.М., Бігел У. та інш./ - 2001.

11. Патент 20698 UA, МПК В01F 7/00. Реактронний гомогенізатор / Л.М. Грабов, В.І. Мерщій, В.Т. Жилеєв.; заявник и патентовласник ІТТФ НАНУ. - №97020627; опубл. 15.04.02, Бюл. №4.

12. Пат. 77487 Україна, МПК В 01 J 6/00. Установка для розігріву та плавлення в'язких систем / Долінський А.А. та інші; заявник та патентовласник: Долінський А.А., Грабов Л.М., Посунько Д.В., Степанова О.С. - № 11634; заявл. 08.10.2012; надр. 11.02.2013, Бюл. № 3.

13. Долінський А.А., Грабов Л.М., Степанова O.Є. Теплообмін при нагріванні і плавленні основ для виготовлення косметичних та фармацевтичних препаратів // Промышленная теплотехника - 2011. - Т. 33, №3. - С. 12-19. 


\section{CREATION AND INTRODUCTION THE EFFECTIVE TECHNOLOGIES AND EQUIPMENT FOR THE MANUFACTURE OF PHARMACEUTICALS. PART 1}

\section{Dolinsky A.A., Grabova T.L., Stepanova O.E.}

Institute of Engineering Thermophysics of the National Academy of Sciences of Ukraine, str., Bulakhovsky, 2, Kyiv, 03164, Ukraine

The dispersed systems such as pharmaceutical forms (PF) are complex multiphase systems with different dynamic, thermodynamic, chemical potential interacting phases from the technological point of view. The compliance with the requirements for PF depends on efficient organization of heat and mass transfer and physical-chemical processes of technologies. The effective technologies using the DPIE method in the devices and equipment for a wide range of $P F$ have been developed and implemented by the Institute of Engineering Thermophysics NASU.

References 13, tables 6, figures 6 .

Key worlds: dispersed system, pharmaceutical form, heat and mass transfer processes, dispersion, melting

1. Dranik L.I. Achievements and Challenges in the Field of soft medicinal forms // Farmakom. 1994, № 4. - P. 17 - 19. (Ukr.)

2. Kozlova N.G. The features of the development of drugs in the form of suppositories / Kozlova N.G., Zamaraeva E.E., Dranik L.I. // Pharmacy. - 1992, V. 41, № 6. - P. 8-83. (Rus.)

3. National Pharmacopoeia of Ukraine/National Enterprise "Scientific and expert pharmacopoeia center". - 1 pub. - Kh.: PIPEG, 2001. - 556 p. (Ukr.)

4. Dolinsky A.A. DPIE principle and its application in industrial processes. $-\mathrm{K}$. Naukova Dumka, 2001 - 346 p. (Ukr.)

5. Dolinsky A.A. DPIE Method in innovative technologies and heat and mass transfer equipment / A.A. Dolinsky, L.N. Grabov, T.L. Grabova //
Industrial heat engineering. - 2012. - V. 34, № 3. P. 18-30. (Rus.)

6. Patent 55709 UA, MПК B01F 7/16, B01F 3/08. Method for hydrodynamic processing of heterogeneous environments and hydrodynamic liquid dispersant mixer for its implementation / L.M. Grabov, V.I. Mershchiy, T.L. Grabova; applicant and patentee -The Institute of Engineering Thermophysics NASU. - №2002053954; published 16.01.06, B. №1. (Ukr.)

7. Dolinsky A.A. Thermophysical methods for creating nanostructured materials with improved properties / A.A. Dolinsky, L.M. Grabov at el. // Industrial heat engineering. - 2010. - V. 32, № 6. P. 5-14. (Ukr.)

8. Grabova T.L. Getting gel systems by the method of hydrodynamic processing // Proceedings ONAFT. - 2010 - pub. 37. - P. 330-334. (Ukr.)

9. Pilov P.I. Simulation of closed grinding circuit based on Rittinger hypothesis / P.I. Pilov, N.S. Pryadko // Mineral processing. - 2012. - pub. 51(92). - P. 92-102. (Rus.)

10. Patent 59460 UA, MПК В01F 7/26. Method for submicron dispersion of multicomponent liquid media and device for its implementation / A.A. Dolinsky, L.M. Grabov, W. Begell at al. - 2001. (Ukr.)

11. Patent 20698 UA, МПК В01F 7/00. Reactron homogenizer / L.M. Grabov, V.I. Merchiy, V.T. Zhyleyev; applicant and patentee the Institute of Engineering Thermophysics NASU. - №97020627; pub. 15.04.02, bulletin. №4. (Ukr.)

12. Patent 77487 UA, МПК В 01 J 6/00. Installation for heating and melting of viscous systems / Dolinsky A.A. at al.; applicant and patentee the Institute of Engineering Thermophysics NASU: A.A. Dolinsky, L.M. Grabov, D.V. Posynko, O.E. Stepanova - № 11634; appl. 08.10.2012; pub. 11.02.2013, bulletin № 3. (Ukr.)

13. Dolinsky A.A., Grabov L.M., Stepanova O.E. Heat transfer during heating and melting the foundations for cosmetics and pharmaceuticals production // Industrial heat engineering. - 2011. V. 33, №3. - P. 12-19. (Ukr.) 